Inokentii Korniienko

Doctor of Psychological Sciences, associate professor,

head of the department of psychology

Mukachevo State University

http://orcid.org/0000-0003-1451-4128.

DOI https://doi.org/10.35619/prap_rv.vi14.157

\title{
THE NARRATIVE COMPONENT OF THE LIFE SCRIPTS ANALYSYS
}

\begin{abstract}
The article is devoted to the analysis of awareness in life scripts based on verbalization of life experience by the subject in the process of narrative interview. A narrative approach aims to make visible phenomena which has already shaped our identity. The purpose of the article is research of narrative psychology opportunities for understanding by the individual the existing life scenario and possibilities of its freeing and expanding, building an autonomous life path, full of responsibility and creativity. It has been pointed out that according to the representatives of the transactional analysis theory the life scenario influences the life path of the personality.

The comedy, the victory of life over death, romance, idealization of the past and traditions; tragedy, that shows the defeat of the hero and his expulsion from the society; irony which is to question all previous narrative structures were distinguished as the narrative structures of personality. It has been discussed that the study of the life scenario has its difficulties and limitations. The use of narrative interviewing creates wide opportunities for a deep understanding of the specifics of the individual's life scenario. The use of this method allows to determine the scriptural beliefs of the person, the further analysis of which is a prerequisite for understanding and correcting the scripted life path.
\end{abstract}

Keywords: narrative, narrative psychology, life experience, life scenario, transactional analysis.

Problem statement. In the modern process of the personality examination, the study of the features of the unfolding process of the life path becomes more relevant. In particular - in the process of awareness by the individual about oneself and own's life. More and more scientists are focusing on biographical methods that allow to get information about the studied subjects. Using an ideographic approach allows to focus on the specific awareness of the individual about oneself, its life-path and life scenario by using a narrative research which refers to a range ways of finding the possibilities of stories in understanding of identity and social life (Riessman, 2008). Narrative approaches recognise that the stories people tell are important; they are worth to be explored in detail, the ways they show the important events of people's lives and their reflections in social identities. Narrative analysis is condensed in stories, often without separating them into themes (Murray, 2003; Riessman, 2008). Because people understand and reflect their experiences through storytelling, the idea of experiences description is the focus of analysis in a narrative approach. Social and cultural similarity provides the building blocks that we use to percept and understand the events of our lives in the texts. Stories are built based on the ideas of how social life should work (Murray, 2018). Because of this, the stories people tell give ideas and statements of the rules for reacting to and interacting with the world, because they reflect broader narratives of social life that we have absorbed (Crossley, 2008). The ideas how we imagine the world to be is seen in the narrative, where some ideas are hard to see, but vital for analysing. Murray (2003) describes this by saying we 'swim in a sea of stories that seeps into our consciousness and our very identity' (98). A narrative approach aims to make visible that which has already shaped our identity. The purpose of the article is research of narrative psychology opportunities for understanding by the individual the existing life scenario and possibilities of exit of its limits; building an autonomous life path, full of responsibility and creativity.

Analysis of recent research and publications. There is no definitive approach to narrative analysis (Polkinghorne, 1995). Different authors have analysed narratives in differently. The ideas they verbalize can be used to analyse the data. Narrative researchers have distinguished "big stories", the highly structured narratives of past events, from "small stories", the everyday social stories (Bamberg \& 
Georgakopoulou, 2008). An important role in the process of exploring life scenario features (the process and mechanisms of its awareness and understanding) is the analysis of personal both "big" and "small" stories. The German sociologist Schutze, who used this method in biographical studies (Zhuravlev, 1993: 33), proposed the method of narrative interview. The development of narrative therapy is associated with the names of White and Epston. In domestic psychology, Rubinstein, Ananiev and their followers (Chepeleva, 2008: 37), carried out the use of an autobiographical approach.

Narrative psychology explores the life history of the individual, by analysing the features of information presentation by the human about oneself and own life. In the basis of narrative approach is the idea that reality does not exist objectively but continuously being constructed in the process of interaction with one another. In the result of this interaction, certain beliefs, values and life positions are being formed, which are represented in the language. Of course, created beliefs and ideas have impact on the process of formation and running of life scripts. That is why the use of a narrative approach is of great importance for deepening the awareness of the personal life scenarios.

By using the word narrative, we shift to the analysis of a scenario, the ways the analyst comes to understand not just what the story says, but what it could mean and how and what with it is connected. Although people tell narratives that are personal, the structures that form these stories belong not just to them (Riessman, 2008). The formation of individual narrative of the personality is affected by the common narrative, inherent to a specific culture. According to $\mathrm{M}$. White, people understand and percept their life by using stories. A person verbalises his own world constantly transforming it by using the language. Telling stories helps people to organize their experience, to turn separate life events into a specific story. Even very personal stories are embedded in the social, cultural, and material conditions which make certain stories and identities available and others unavailable (Silver, 2013). In narrative psychology the concept of narrative indicates as a plot of the story, a story about oneself, which the person builds under the influence of interaction with it's environment (Chepeleva, 2008: 21). This is what narrative psychology is about: "the structure, content, and function of the stories that we tell each other and ourselves in social interaction" (Murray, 2003: 95). Narrative provides an opportunity for the scientist to learn many personal features, i.e. self-representation, self-identification, features of life world and life space construction, explain of the causes of events, important decisions etc.

One of the important theoretical foundations of narrative interview is the presence of intuitive skills of building and telling stories common for every human. The presence of such skill serves as the warranty that the story told by the individual will be clear to other people, in a particular its social context and in a specific cultural environment. Each story of the individual about oneself and own life is built according to certain rules. During researches, German scientist F. Schütze identified the following basic rules for constructing a story (Zhuravlev, 1993: 33): integrity and completeness; thickening; detailing.

The integrity and completeness are manifested in the narrator's desire to combine parts of the story into a completely one structure and bring the story to its logical conclusion. Thickening is a focus of the narrator on only those facts, which had an important meaning in his life. The introduction of a new character, new events etc. requires dualization and specification which are not always available. Distinguishing the narrative structures of personality psychologists point out the following: "comedy" (the victory of life over death); "romance" (idealization of the past and traditions); "tragedy" (shows the defeat of the hero and his expulsion from the society); "irony" (question all previous narrative structures, if they do not cope with the construction of vital meanings) (Havrychenko, 2008). Thus, the process of the life-path can hold various events, which always find their expression at the level of narrative structures.

Basic material and results of the study. Understanding the characteristics of the life scenario requires the extraction of specific components - personal meanings, which a person operates with in the process of the interpretation of own life experience. Scientists of narrative psychology indicate that comprehension and realization of personal experience evolves to the concept, that in narrative psychology is defined as "personal myth". At first this concept (personal mythology) was suggested that E. Crist in 1956 (Chepeleva, 2008: 74). He used this concept to encircle hardly describable elements of human consciousness. There is no clear definition of this concept among scholars on this field yet. But the 
scientists agree on the fact that personal myth has got a verbal component, which is filled with sensual, figurative, symbolic components. The specificity of this formation is to generate "excess" meaning.

The significant feature of personal mythology is that it is almost not reflected, it is difficult to distinguish it in the context of the personal worldview. Personal mythology is a way of arranging the experience. It works as a lens that colors the perception in accordance with own assumptions and values. In the process of this perception, certain values are being pointed out while others go into the background. People, while living the life, almost do not recognize own "lens" through which they percept the world. The concept of "personal myth" has significant similarities with the concept of "life script" that is developed in the theory of transactional analysis (TA). The life scenario also distorts the perception of life situations, eliminating from consciousness (or exaggerating) some aspects of the real situation. So, instead of solving the problem "a person relies on the "magic" solution, which is proposed by the scenario" (Berne, 2001: 195).

According to the representatives of the transactional analysis theory the life path of the personality is influenced by the life scenario. Life scenario is a subconscious life plan of a person, which determines his actions, prospects and thoughts. The most developed classifications of life scenario types in TA theory is the classification of E. Bern and K. Steiner. Eric Berne identified the following groups of scenarios: winning; losing (fatal); banal scenarios (winless). Thus, the implementation scenario by the individual may vary in the quality of the one who wins (winning script), the one that loses (fatal scenario) or the one who does not win (a banal script). Another representative of transactional analysis, Karl Steiner, offered his own classification of life scenarios (based on the predominance of an emotional disorder). $\mathrm{He}$ identified the following three life scenarios: "Without love" (depression); "Without mind" (madness); "Without joy" (dependences) (Steiner, 1990: 58).

In classification of life scenarios E. Bern emphasizes achieving or not achieving certain goals or how comfortable is the process of achieving for the personality. In K. Steiner's approach, we see a classification that has got more "emotional" approach, which is reflected in the names of life scenarios. Thus, the scenario "without love" is peculiar to people who seek close relations, but cannot find them. The scenario "without mind" is connected with the fear of a person to become or to be seem as crazy. In the scenario "without joy" is a person who does not feel or understand oneself, own needs, which is emotionally distant from oneself. The presence of a certain life scenario will find its reflection at the level of the personal narrative. The life scenario is the subconscious basic level of personal decisions making about oneself and own life: who to be with, what to become, where to be. These beliefs are formed in the personality under the influence of parental programming. It should be noted that a "child" at an unconscious level (Erskine, 2010: 24) mostly makes the decision within a certain life scenario. The life scenario has an impact on the subsequent life of the person and manifested in his actions, believes relationships with the environment (Hay, 1996). However, these influences, in most cases, are not conscious for the personality. Because the narrative structures of the personality relate to his life experience, they include interpretation and attitude to own life path. The analysis of narratives allows to highlight the scenario beliefs of the subject and to make further correction of negative thoughts and actions about oneself and own life. Narrative is a verbalised life scenario. A person talks about himself, his life, his plans for the future, past events and many more. Important information for life scenario understanding can be found in the stories. The task of the researcher is to analyse personal narratives deep and full enough. Getting answers to questions about everyday decisions can emerge the picture of a current life scenario of the personality.

Thus, the script is stored at an unconscious level. The narrative is a verbalization of personal experience, which can be shifted to the level of consciousness, to something understandable and recognizable. Therefore, to bring the scenario to the level of awareness, the creation of a personal life story about oneself and own life is truly necessary. Stories about personal experiences are assumed beneficial for one's well-being, as this implies that the individual has been able to make meaning out of that particular experience (Boals et al., 2011). In contrast, narrating in a very incoherent manner is thought to be related to psychopathology. The coherence of young adults' autobiographical narratives of personally significant events has been found to be positively associated with psychological well- being, with the experience of purpose and meaning in life and with maintaining positive relationships (Waters and Fivush, 2015), and negatively associated with depressive symptoms (Vanderveren et al., 2019). 
However, the awareness process and understanding of own life scenario cannot be done solely on the basis of narrative. It is necessary to give feedback; the researcher must return to the client his own narrative while exacerbating certain moments in the story (by means of questions), which may be manifestations of client's life scenario. Further analysis of those manifestations may help to bring the scenario of the client to a higher stage of awareness, which in turn will allow the process of reversal or modification of the existing life scenario of the personality (Goulding, 1979: 42). Living scenario research involves not only the use of the narrative interview methods. For a deep understanding of this phenomenon, projective techniques can also be used. However, analysis of narrative structures, undoubtedly, will help optimize the process of studying the scenarios of personality living path.

Conclusions and Prospects. Therefore, the study of the life scenario has its difficulties and limitations, which are due to the object of the study while the scenario is an unconscious structure. However, the use of narrative interviewing creates wide opportunities for a deep understanding of the specifics of the individual's life scenario. The use of this method allows to determine the scriptural beliefs of the person, the further analysis of which is a prerequisite for understanding and correcting the scripted life path. Integration of the transactional analysis method with the narrative approach will allow to deepen the understanding on the formation of the human life scenario and the possibilities of its psychological correction based on the analysis of the narrative structures.

\section{СПИСОК ПОСИЛАНЬ}

Берн, Э. (2001). Игры, в которые играют люди. Психология человеческих взаимоотношений; Люди, которые играют в игры. Психология человеческой судьбы. Екатеринбург: Литур.

Гавриченко, О. В. (2008). Нарратив как метод исследования психологических особенностей личности подростка. Взято с http://www.allpsychology.ru/modules.php? name $=$ Pages $2 \& \mathrm{go}=$ page $\&$ pid $=2$

Журавлев, В. Ф. (1993). Нарративное интервью в биографических исследованиях. Социология: 4, 3-4, 34-43.

Чепелєва, Н. В. (2008). Соціально-психологічні чинники розуміння та інтерпретації особистого досвіду. Інститут психології імені Г. С. Костюка АПН України. Київ: Педагогічна думка.

Чепелєва, Н. В. (2004). Проблеми психологічної герменевтики. Інститут психології імені Г. С. Костюка АПН України. Київ: Міленіум.

Стюарт, Й., \& Джойнс, В. (2002). Основи ТА: транзакиійний аналіз. Київ: ФАДА, ЛТД.

Bamberg, M., \& Georgakopoulou, A. (2008). Small stories as a new perspective in narrative and identity analysis. Text \& Talk, 28, 377-396.

Silver, J. (2013). Narrative psychology. In C. Willig (Ed.), Introducing qualitative research in psychology (pp. 143-155). Berkshire: Open University Press.

Boals, A., Banks, J., Valentine, L., \& Schuettler, D. (2011). Coping with Stressful Events: Use of Cognitive Words in Stressful Narratives and the Meaning-Making Process. Journal of Social and Clinical Psychology, 30, 378-403.

Crossley, M. (2008). Narrative analysis. In E. Lyons, A. Coyle (Eds.), Analysing qualitative data in psychology (pp. 131-144). London: Sage.

Erskine, R. (2010). Life scripts: a transactional analysis of unconscious relational patterns. Karnac.

Goulding, M. M., \& Goulding, R. L. (1979). Changing lives through redecision therapy. New York: Brunner/Mazel.

Hay, J. (1996). Transactional Analysis for Trainers. Sherwood Publishing.

Murray, M. (2003). Narrative psychology and narrative analysis. In P. M. Camic, J. E. Rhodes, L. Yardley (Eds.), Qualitative research in psychology: Expanding perspectives in methodology and design (pp. 95-112). Washington, DC: American Psychological Association.

Murray, M. (2018). Narrative data. In U. Flick (Ed.), Sage handbook of qualitative data collection (pp. 264-279). London: Sage.

Polkinghorne, D. E. (1995). Narrative configuration in qualitative analysis. International Journal of Qualitative Studies in Education, 8(1), 5-23.

Riessman, C. K. (2008). Narrative methods for the human sciences. Thousand Oaks: Sage.

Steiner, C. (1990). Scripts People Live: Transactional Analysis of Life Scripts. (2nd ed.). Grove Press. 
Vanderveren, E., Bijttebier, P., \& Hermans, D. (2019). Autobiographical memory coherence and specificity: examining their reciprocal relation and their associations with internalizing symptoms and rumination. Behav. Res. Ther, 116, 30-35.

Waters, T. \& Fivush, R. (2014). Relations Between Narrative Coherence, Identity, and Psychological Well-Being in Emerging Adulthood. Journal of personality, 83(4).

\section{REFERENCES}

Bern, E. (2001). Igry, v kotoryye igrayut lyudi. Psikhologiya chelovecheskikh vzaimootnosheniy; Lyudi, kotoryye igrayut v igry. Psikhologiya chelovecheskoy sud'by. [Games People Play. Psychology of human relationships; People who play games. The psychology of human destiny.]. Ekaterinburg: Litur. [in Russian].

Gavrichenko, O. V. Narrativ kak metod issledovaniya psikhologicheskikh osobennostey lichnosti podrostka [Narrative as a method of research into the psychological features of a teenager's personality]. Vzyato $\mathrm{s}$ http: // www. allpsychology.ru/modules.php?name=Pages2 $\&$ go=page \&pid=23 [in Russian].

Zhuravlev, V. F. (1993). Narratyvno interv'yu u biohrafichnykh doslidzhennyakh. [Narrative interview in biographical research]. Sociology: 4, 3-4, 34-43. [in Russian].

Chepeleva, N. V. (2008). Sotsial'no-psykholohichni chynnyky suchasnoho ta interpretatsiynoho rivnya dosvidu. [Socio-psychological factors of understanding and interpretation of personal experience]. Institute of Psychology G. S. Kostyuk APS of Ukraine. Kyiv: Pedahohichna dumka. [in Ukrainian].

Chepeleva, N. V. (2004). Problemni psykholohichni hermenevtyky. [Problems of psychological hermeneutics]. Institute of Psychology G. S. Kostyuk APS of Ukraine. Kyiv: Millennium. [in Ukrainian].

Stuart, J., \& Joynes, V. (2002). Osnovy TA: tranzaktsiynyy analiz. [Fundamentals of TA: Transactional Analysis]. Kiev: FADA, LTD. [in Ukrainian].

Bamberg, M., \& Georgakopoulou, A. (2008). Small stories as a new perspective in narrative and identity analysis. Text \& Talk, 28, 377-396. [in English].

Silver, J. (2013). Narrative psychology. In C. Willig (Ed.), Introducing qualitative research in psychology (pp. 143-155). Berkshire: Open University Press. [in English].

Boals, A., Banks, J., Valentine, L., \& Schuettler, D. (2011). Coping with Stressful Events: Use of Cognitive Words in Stressful Narratives and the Meaning-Making Process. Journal of Social and Clinical Psychology, 30, 378-403. [in English].

Crossley, M. (2008). Narrative analysis. In E. Lyons, A. Coyle (Eds.). Analysing qualitative data in psychology. (pp. 131-144). London: Sage. [in English].

Erskine, R. (2010). Life scripts: a transactional analysis of unconscious relational patterns. Karnac. [in English].

Goulding, M. M., \& Goulding, R. L. (1979). Changing lives through redecision therapy. New York : Brunner/Mazel. [in English].

Hay, J. (1996). Transactional Analysis for Trainers. Sherwood Publishing. [in English].

Murray, M. (2003). Narrative psychology and narrative analysis. In P. M. Camic, J. E. Rhodes, \& L. Yardley (Eds.), Qualitative research in psychology: Expanding perspectives in methodology and design (pp. 95-112). Washington, DC: American Psychological Association. [in English].

Murray, M. (2018). Narrative data. In U. Flick (Ed.), Sage handbook of qualitative data collection (pp. 264-279). London: Sage. [in English].

Polkinghorne, D. E. (1995). Narrative configuration in qualitative analysis. International Journal of Qualitative Studies in Education, 8(1), 5-23. [in English].

Riessman, C. K. (2008). Narrative methods for the human sciences. Thousand Oaks: Sage. [in English].

Steiner, C. (1990). Scripts People Live: Transactional Analysis of Life Scripts. (2nd ed.). Grove Press. [in English]. 
Vanderveren, E., Bijttebier, P., \& Hermans, D. (2019). Autobiographical memory coherence and specificity: examining their reciprocal relation and their associations with internalizing symptoms and rumination. Behav. Res. Ther, 116, 30-35. [in English].

Waters, T. \& Fivush, R. (2014). Relations Between Narrative Coherence, Identity, and Psychological Well-Being in Emerging Adulthood. Journal of personality, 83(4). [in English].

\section{НАРРАТИВНИЙ КОМПОНЕНТ АНАЛІЗУ СЦЕНАРІЇВ ЖИТТЯ}

Інокентій Корніснко

доктор психологічних наук, доцент,

завідувач кафедри психології

Мукачівського державного університету

http://orcid.org/0000-0003-1451-4128.

DOI https://doi.org/10.35619/prap_rv.vi14.157

Анотація. Стаття присвячена аналізу усвідомлення життєвих сиенаріїв на основі вербалізації життєвого досвіду суб'єктом у проичесі розповідного інтерв'ю. Наративний підхід має на меті зробити видимим те, щзо вже сформувало нашу ідентичність. Мета статті дослідження можливостей наративної психологї для розуміння індивідом існуючого життєвого сиенарію та можливостей виходу з його меж, вибудовуючи автономний життєвий шлях, сповнений відповідальності та творчості. Було зазначено, щуо, на думку представників теорії трансакиійного аналізу; життєвий сценарій впливає на життєвий илях особистості.

«Комедія», перемога життя над смертю; "романтика», ідеалізація минулого та традииій; «трагедія», яка показує поразку героя та його вигнання із суспільства; «іронія» оповіді виокремлюються, як оповідні структури особистості. Обговорюється, щзо вивчення життєвого сценарію має свої труднощі та обмеження. Використання розповідного інтерв'ю створює широкі можливості для глибокого розуміння специфіки життєвого сиенарію індивіда. Використання цьього методу дозволяе визначити духовні переконання особистості, подальший аналіз яких є необхідною умовою розуміння та корекиії сценарності життєвого шляху.

Ключові слова: нарратив, нарративна психологія, життєвий досвід, життєвий сиенарій, транзакиійний аналіз.

Стаття надійшла до редакиї̈ 15.01.2020 p. 